in the social hierarchy of the city are outlined. The main religious groups in the cities of left-bank Ukraine and their impact on the community life are considered.

Common features and regional peculiarities in the formation of city self-government bodies, the percentage of population that took part in the formation of self-government bodies are presented.

Based on the use of the method of historical statistics, the educational level of urban residents who participated in the activities of self-government bodies, are determined. The reasons for the ineffectiveness of self-governing bodies are stated.

Key words: Left-bank Ukraine, modernization, reforms, cities, urban population, self-government.

Дата надходження статті до редакції: 12.02.2018.

\title{
Олена Петасюк
}

\section{УКРАÏНСЬКІ КООПЕРАТОРИ У ПЕРШОМУ СКЛАДІ ГЕНЕРАЛЬНОГО СЕКРЕТАРІАТУ: ДО БІОГРАФІЧНОГО ПОРТРЕТУ}

\begin{abstract}
Предметом дослідження є аналіз світоглядно-ідеологічного бекграунду українського кооперативного руху через призму діяльності знакових його персоналій кіния XIX - перших десятиліть ХХ cm. Висвітлюються постаті міністрів-кооператорів у складі першого українського уряду. Констатується, що українська кооперація була осередком національно свідомих сил в часи визвольних змагань 1917-1921 рр.
\end{abstract}

Ключові слова: українська кооперація, кооперативний рух, кооператори, генеральні секретарі, національна свідомість.

Українська кооперація стала одним з головних джерел постачання творчих сил для національної революції 1917-1921 рр. Провідні діячі українського кооперативного руху як носії прогресивного світогляду намагалися вбудувати демократичні засади діяльності кооперативів в основи тогочасного господарського життя та громадського спілкування.

Кооперування демонструвало добровільність об'єднань, вільний вступ до них та вихід з їх лав; право виробника володіти та самостійно розпоряджатися результатами власної праці, рівно як і засобами виробництва, що використовуються для ix досягнення; рівномірне користування вигодами, які надані загальним підприємством; участь пайщиків в управлінні справами кооперативу незалежно від розміру паю; опора на ідеали самоуправління та взаємодопомоги. Один $з$ головних принципів економічної кооперації полягав в тому, що чисті заробітки розподілялися безпосередньо (здебільшого щорічно) серед кооперативних партнерів і не правили за джерело прибутку для якоїсь окремої групи власників чи інвесторів.

3 моменту свого виникнення (у $1860-\mathrm{x}$ рр. на підросійських українських землях) кооперація із практичного втілення ідей виховної громадської організації переросла в осередок національно свідомих сил, які не могли не брати активну участь у подіях української національної революції і стали щирими співучасниками державного відродження в Україні. Показово, що царський уряд вбачав у кооперативному русі ще на світанку його розвитку інтелігентську опозицію режимові, а радикальні російські кола осоружний західноєвропейський імпорт. У формі кооперативної діяльності була тоді нагода різним суспільним діячам здійснювати власні програмні завдання. До кооперативного руху пристало чимало розчарованих революцією 1905-1907 pp., бо вони вбачали у ньому конкретний засіб демократичної розбудови суспільства.

Кооперативний рух, що в основі своїй спирався на місцеву автономію й добровільну самодіяльність і спрямовував організаційну побудову знизу вгору, виявився принадним засобом для неросійських національностей імперії у плані громадсько-політичного життя. Кооперацію вони розцінювали як важливу передумову для свого соціального та національного піднесення, освіти широких мас населення. 
Науковий інтерес до історії кооперативного руху відродився 3 початком радянської перебудови і орієнтацією на ринкову модель розвитку. Одними з перших дослідників українського кооперативного руху стали М. Аліман, С. Гелей, В. Марочко, Р. Матейко та інші. Для їхніх досліджень характерним $€$ розгляд кооперативного розвитку у загальноєвропейському та національному контекстах. Сучасна концепція кооперативного розвитку в Україні, представлена працями В. Власенка, І. Гарбузової, О. Двойнінової та інших, продовжує традиції інтересу до історіографії проблеми, історії розвитку видового розмаїття кооперації (промислова, сільськогосподарська, кредитна). Дослідницька оптика наводиться на історично-економічні райони, як-от: Правобережжя, Лівобережжя, Південна та Західна Україна. В аспекті хронологічних меж досліджень передусім вивчається період другої половини XIX ст., початок XX ст. і час до національної революції 1917-1921 pp. Недостатньо уваги приділяється саме розвитку кооперативного руху під час української національної революції.

Розглянемо грані діяльності українських кооператорів та з'ясуємо, які стежини привели їх до державної служби у 1917 р. (загалом біографії цих непересічних постатей надзвичайно багаті, насичені різноманітними подіями). Таким чином ми спробуємо визначити ідеологічне підгрунтя українського кооперативного руху через призму діяльності носіїв тогочасного прогресивного світогляду — кооператорів.

На різних з'їздах, що відбувалися тоді по всій Україні, головували часто-густо кооперативні інструктори, керівники кооперативних спілок, учасники рад і правлінь сільськогосподарської кооперації. На початку революції кооператори обіймали провідні посади в земських управах. Кооперативна діяльність виробила в них громадську ініціативу, адміністраторські здібності, вміння переконувати реальними фактами, використовуючи ораторський хист. Більшість із цих людей мала вищу освіту, пробувала себе у педагогічній діяльності, тобто кооператори на той час були передовими представниками свого народу, мали авторитет серед населення, передусім завдяки власній порядності та щирій відданості справі. Тому невипадково із лав кооперації вийшла плеяда українських державних діячів. Половину першого складу Генерального Секретаріату становили українські кооператори - генеральні секретарі Христофор Барановський (міністр фінансів, безпартійний), Борис Мартос (міністр земельних справ, УСДРП), Микола Стасюк (міністр продовольчих справ, УПСР), генеральний писар Павло Христюк (УПСР).

Так, Христофор Антонович Барановський (1874-1941) до національної революції був уже відомим громадським діячем на центральних та східних землях України. Вийшовши із селянської родини, не маючи середньої та вищої освіти, виявив він хист фінансиста і був головною особою у початковий період боротьби української кооперації за власне будівництво спілок, що тривало протягом першого десятиріччя XX ст. (1913 р. українські кооперативні спілки були ліквідовані владою). Засновник і директор Союзбанку центру дрібного кредиту (1907-1917), з 1917 р. голова Управи Українського кооперативного банку, він фактично був при організації усіх верховних кооперативів, зокрема Українбанку (центру кредитної кооперації), Централу (сільськогосподарський кооперативний центр), Страхсоюзу. Крім того, Христофор Антонович редагував кооперативний часопис «Комашня» (орган Київського Союзу Установ Дрібного Кредиту) у Києві, написав багато праць на тему кооперації. Після поразки української національної революції (з 1920 р.) емігрував у Південну Америкуㄷ․

Примітною постаттю українського кооперативного руху і активним громадсько-політичним діячем, педагогом, дійсним членом НТШ, ВУАН був Борис Миколайович Мартос (1879-1977). Походив він зі старого козацько-старшинського роду на Полтавщині (до слова, саме коштом одного з його представників 1840 р. був виданий «Кобзар» Тараса Шевченка). Ще у студентські роки за допомогу РУП його неодноразово арештовували (1908р. закінчив математичний факультет Харківського університету). Викладав у Київському комерційному інституті, був одним із засновників Кооперативного інституту ім. М. Туган-Барановського у Києві. До національної революції Борис Мартос працював як кооператор на Волині та Кубані, інспектував кооперативний рух у Полтавському губземстві. Деякий час очолював виконавчий орган Центрального українського кооперативного комітету, був членом Ради директорів Дніпросоюзу - центру споживчої кооперації, заснованого 1917 р. До складу УЦР обраний на I Всеукраїнському селянському з'ізді ${ }^{2}$. 1920 р. - в еміграції. Його подальший життєвий шлях проліг через Німеччину, Чехословаччину, США. За кордоном продовжував викладання, став одним 3 організаторів і керівників Української Господарської Академії уПодєбрадах, УкраїнськоїВищоїшколиекономіки

1 Енциклопедія українознавства. Словникова частина / голов. ред. В. Кубійович. Перевид. в Україні; репринт. відтвор. видання 1955-1984 [у 11 т.]. Л.: НТШ, 1993. Т. 1: Абаза-Голов'янко. С. 91.

2 Верстюк В., Осташко Т. Діячі Української Центральної Ради. Біографічний довідник. К.: Віддруковано на Київ. нот. ф-ці, 1998. С. 122-123; Енциклопедія українознавства. Словникова частина / голов. ред. В. Кубійович. Перевид. в Україні; репринт. відтвор. видання 1955-1984 [у 11 т.]. Л.: НТШ, 1994. - Т. 4: Крушельницький-Місто. С. 1480. 
у Мюнхені. Певний час перебував на посадах президента, віце-президента і секретаря вченої ради Інституту вивчення СРСР (Мюнхен). Автор праць «Теорія кооперації (1924), «Кооперативна ревізія» $(1927)^{3}$, «Гроші української держави» (1972, у співавторстві із Я. Зозулею) та багатьох інших.

Микола Михайлович Стасюк (18851943?) - дворянського походження, родом 3 Катеринославщини. Там же організовував селянські кооперативні спілки (за що був заарештований). Належав до кооперативної школи Христофора Барановського. Переймався поширенням «Громадської думки» - першої газети українською мовою на східноукраїнських землях. Здобув вищу освіту у Гірничому інституті (Петербург). Як згадують його сучасники, завжди цікавився економічним боком української справи. Ще до національної революції вийшли його праці «Автономія і розвиток продукційних сил на Вкраїні» (1908), «Еміграція та ії значення в економічному житті України» (1912). Микола Стасюк був одним із засновників УЦР, затверджений Радою промовцем на мітингах під час української національної маніфестації 19 березня 1917 р. Виступаючи на мітингу, звернувся до українців із закликом «стерти в пам'яті і з п’єдесталу монумента Хмельницькому слова “волимо під царя московського”». На з'їзді діячів українського села (Київ, 1917) М. Стасюка було обрано головою Тимчасового комітету новоутвореної Української селянської спілки й делеговано на Всеукраїнський національний конгрес. В УЦР він активно займався організаційною, агітаційною роботою. 3 с створенням Генерального Секретаріату 15 червня 1917 року його кандидатуру було затверджено на посаді генерального секретаря харчових справ, яку обіймав до серпня ${ }^{4}$.

3 еміграції М. Стасюк повернувся у 1920-х рр., 1933 р. його репресували за сфабрикованою ще 1931 р. справою Українського національного центру, спрямованою на винищення українських національно свідомих інтелектуалів. Донедавна на цьому і завершувалася біографія людинипатріота, енергійного кооператора. Стараннями краєзнавців та науковців було відновлено інформацію про останні роки життя неординарної людини. Микола Стасюк відбував ув'язнення на карельському лісоповалі, працював на будівництві Біломорсько-Балтійського каналу, де кожний будівничий каналу позначався «з/к», тобто рос. «заключенный каналоармеец» (розмовною «зек»). 1940 р. під наглядом «органів» сторожував у Маріупольському парку. 3 початком Другої світової війни був одним 3 організаторів антигітлерівського оунівського підпілля, редактором

\footnotetext{
3 Верстюк В., Осташко Т. Діячі Української Центральної Ради... С. 123.

4 Там само. С. $162-163$.
}

«Маріупольської газети». Сліди його губляться 1943 р. поблизу Маріуполя. Неоціненними є його мемуари «На межі божевілля» (1941-1942) ${ }^{5}$.

Ім'я Павла Оникійовича Христюка (18901941), як і попередніх кооператорів, за радянських часів було викреслене з контексту української історії та історичної пам'яті. Він відомий також не тільки як політичний діяч, але i як кооператор та публіцист. Походив із родини кубанського козака-хлібороба. Вищу освіту здобув у Київському політехнічному інституті. У «Замітках і матеріалах до історії української революції» досить чітко окреслив причини приставання до кооперативної праці, як власні, так i тогочасної громадськості: через слаборозвинене національне політичне життя на кооперативну роботу йшли у дореволюційні часи свідомі сили української демократії, які прагнули працювати на громадському грунті. Павло Христюк у свій час став одним з редакторів вже згадуваної «Комашні». Відшуковуємо його і серед засновників та діячів Центрального українського кооперативного комітету - організаційного центру української кооперації. На першому кооперативному з'їзді Київщини (березень 1917 р.), що був одразу сприйнятий як явище національно-визвольного руху, цю особу обрали до президії з’їзду та секретарем. Тоді було ухвалено постанову про негайне введення української мови у школі, суді, церкві, громадських та державних інституціях. На першому Кооперативному з'їді спілок України П. Христюка разом з М. Ковалевським було обрано редакторами непартійної газети «Народна воля», що швидко завоювала симпатії українського селянства. 3 червня Павло Христюк репрезентував в УЦР Селянську спілку та Всеукраїнську раду селянських депутатів. Комітет УЦР 15 червня 1917 р. призначив його генеральним писарем першого українського уряду. Підпис П. Христюка скріплював найважливіші документи УЦР та Генерального Секретаріату ${ }^{6}$.

Згодом, так само у період непу повертається до України із Австрії, де, до речі, завідував закордонним представництвом Вукоспілки - центру радянської споживчої кооперації. В УСРР працював в основному у таких галузях гуманітарного знання, як літературознавство, історична наука. Певний час працював в Українбанку. Як i М. Стасюка, П. Христюка заарештовують 1931 р. і звинувачують у причетності до так званого УНЦ. Після довготривалих поневірянь він загинув у «Севвостлаге» Архангельської області 7 .

5 Чабан М. Стасюк Николай Михайлович. URL: https://gorod.dp.ua/tema/persons/?pageid=2104 (дата звернення: 31.01.2018)

6 Верстюк В., Осташко Т. Назв. праця. С. 179-180.

7 Шаповал Ю. Генеральний писар // Літературна Україна. 1994. 28 квітня. С. 7. 
Зважаючи на вищевикладене, можемо констатувати, що шлях «кооперація - громадська діяльність - політика - державна служба» був не випадковим кроком для згаданих нами осіб, а своєрідним логічним ланцюгом їхньої діяльності, що, з іншого боку, можна розглядати і як сходинки зростання національної самосвідомості українських діячів. Узагальнення кооперативного досвіду, вивчення кооперативних традицій та постатей допоможе виділити його національні особливості, додати важливих штрихів до соціально-економічного та політичного обличчя України, врахування яких допоможе при розробці сучасної економічної стратегії.

\section{ДЖЕРЕЛА}

1. Енциклопедія українознавства. Словникова частина / голов. ред. В. Кубійович. - Перевид. в Україні; репринт. відтвор. видання 1955-1984 [в 11 т.]. - Л. : НТШ, 1993. - Т. 1: АбазаГолов'янко. -399 с.

2. Енциклопедія українознавства. Словникова частина / голов. ред. В. Кубійович. - Перевид. в Україні; репринт. відтвор. видання 1955-1984 [в 11 т.]. — Л. : НТШ, 1994. — Т. 4: КрушельницькийМісто. - С. 1205-1599.

3. Верстюк В. Діячі Української Центральної Ради. Біографічний довідник / В. Верстюк, Т. Осташко. - К. : Віддруковано на Київ. нот. ф-ці, 1998. - 254 с.

4. Чабан М. Стасюк Николай Михайлович [Електронний ресурс] / М. Чабан. - Режим доступу : https://gorod.dp.ua/tema/persons/?pageid=2104

5. Шаповал Ю. Генеральний писар / Ю. Шаповал // Літературна Україна. — 1994. — 28 квітня. — C. 7.

\section{REFERENCES}

1. Kubiyovich, V. (Ed.). (1993). Entsyklopediia ukrainoznavstva. Slovnykova chastyna. Vol. 1. Lviv: NTSh, 399 p. [in Ukrainian].

2. Kubiiovych, V. (Ed.). (1994). Entsyklopediia ukrainoznavstva. Slovnykova chastyna, Vol. 4, Lviv: NTSh, pp. 1205-1599 [in Ukrainian].

3. Verstiuk, V., \& Ostashko, T. (1998). Diiachi Ukrainskoi Tsentralnoi Rady. Biohrafichnyi dovidnyk. Kyiv: Viddrukovano na Kyiv. not. f-tsi, 254 p. [inUkrainian].

4. Chaban, M.StasiukNikolai Mikhailovich [in Ukrainian].https://gorod.dp.ua/tema/persons/?pageid=2104

5. Shapoval, Yu. Heneralnyi pysar. (1994). Literaturna Ukraina, 28 kvitnia, p. 7 [inUkrainian].

\section{Olena Petasyuk}

\section{COOPERATORS AS PART OF THE FIRST MEMBERSHIP OF THE GENERAL SECRETARIAT OF UKRAINE: TO THE BIOGRAPHICAL PORTRAIT}

The topic of the study is the ideological background of the Ukrainian cooperation. Edges of activity of such progressive worldview carriers as the cooperators are revealed. Most of them became the victims of The Great Purge of Stalin. This article analyses the following questions: "the appreciation of the cooperation of XIX - XX centuries"; "why it became the source of providing the personnel for the National revolution". Personalities of ministers-cooperators as part of the first Ukrainian government are introduced. It is stated that Ukrainian cooperation was the center of the patriotic forces.

The half of the first membership of The General Secretariat of Ukraine was composed of cooperators such as Khrystophor Baranovskiy, Mykola Stasyuk, Borys Martos and Pavlo Khrystyuk. They were educated and authoritative people. They had a rich experience and active national views. The Soviet power didn't need people with such characteristics.

The lessons of the historical experience and study of traditions of the Ukrainian cooperation will help to add certain traits to the socio-economic and political development of Ukraine.

Key words: Ukrainian cooperation, cooperation movement, cooperators, the Secretaries-General, national consciousness. 